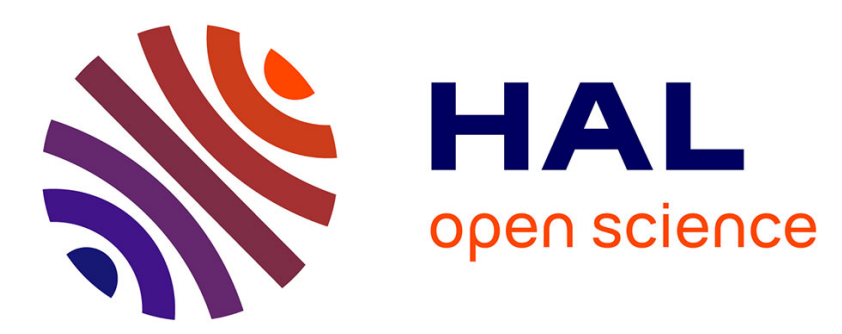

\title{
Are ditch networks optimised for mitigating rill erosion in cultivated Mediterranean landscapes? A numerical experiment
}

Florent Levavasseur, Jean-Stéphane Bailly, Philippe Lagacherie

\section{- To cite this version:}

Florent Levavasseur, Jean-Stéphane Bailly, Philippe Lagacherie. Are ditch networks optimised for mitigating rill erosion in cultivated Mediterranean landscapes? A numerical experiment. Land Use Policy, 2016, 50, pp.441 - 448. 10.1016/j.landusepol.2015.08.033 . hal-01381108

\author{
HAL Id: hal-01381108 \\ https://hal.science/hal-01381108
}

Submitted on 15 Jun 2018

HAL is a multi-disciplinary open access archive for the deposit and dissemination of scientific research documents, whether they are published or not. The documents may come from teaching and research institutions in France or abroad, or from public or private research centers.
L'archive ouverte pluridisciplinaire HAL, est destinée au dépôt et à la diffusion de documents scientifiques de niveau recherche, publiés ou non, émanant des établissements d'enseignement et de recherche français ou étrangers, des laboratoires publics ou privés. 


\title{
Are ditch networks optimised for mitigating rill erosion in cultivated Mediterranean landscapes? A numerical experiment
}

\author{
F. Levavasseur ${ }^{\mathrm{a}, \mathrm{b}}$, J.S. Bailly ${ }^{\mathrm{c}, \mathrm{d}, *}$, P. Lagacherie ${ }^{\mathrm{a}}$ \\ a INRA, UMR LISAH, F-34060 Montpellier, France \\ b INRA, UMR SAD-APT, F-78850 Thiverval-Grignon, France \\ ${ }^{c}$ AgroParisTech, UMR LISAH, F-34060 Montpellier, France \\ d AgroParisTech, UMR TETIS, F-34093 Montpellier, France
}

\section{Introduction}

The erosion of cultivated soils poses a significant threat to communities and agricultural areas, especially in Mediterranean areas where high rainfall intensities, depleted topsoil organic matter contents and low vegetation coverage due to land use (e.g., vineyards and orchards) increase the erosion risks. Among the range of dis-services induced by erosion, the occurrence of rill erosion in

\footnotetext{
Corresponding author at: AgroParisTech, UMR LISAH, F-34060 Montpellier, France.

E-mail addresses: florent.levavasseur@grignon.inra.fr (F. Levavasseur), bailly@agroparistech.fr (J.S. Bailly), lagacherie@supagro.inra.fr (P. Lagacherie).
}

cultivated fields is recognised by farmers because it indicates soil loss and could be costly to avoid and repair.

This clear perception of the effects of rill erosion may explain why Mediterranean farmers have historically adopted soil conservation practices to mitigate rill erosion, including building terraces that reduce slope and runoff velocity (Ramos and Porta, 1997; Roose and Sabir, 2002; Blondel, 2006; Bevan and Conolly, 2011; Stanchi et al., 2012; Tarolli et al., 2014), building ditches that intercept runoff (Ramos and Porta, 1997; Roose and Sabir, 2002; Tarolli et al., 2015) and benching terraces to stop runoff on hill-slopes (Wheaton, 2001; Nasri, 2007). However, these practices represent non-negligible settlement costs and generate indirect costs for farmers by reducing field sizes, decreasing field accessibility and inducing additional maintenance work (Martnez-Casasnovas and Ramos, 2006; Petanidou et al., 2008). 


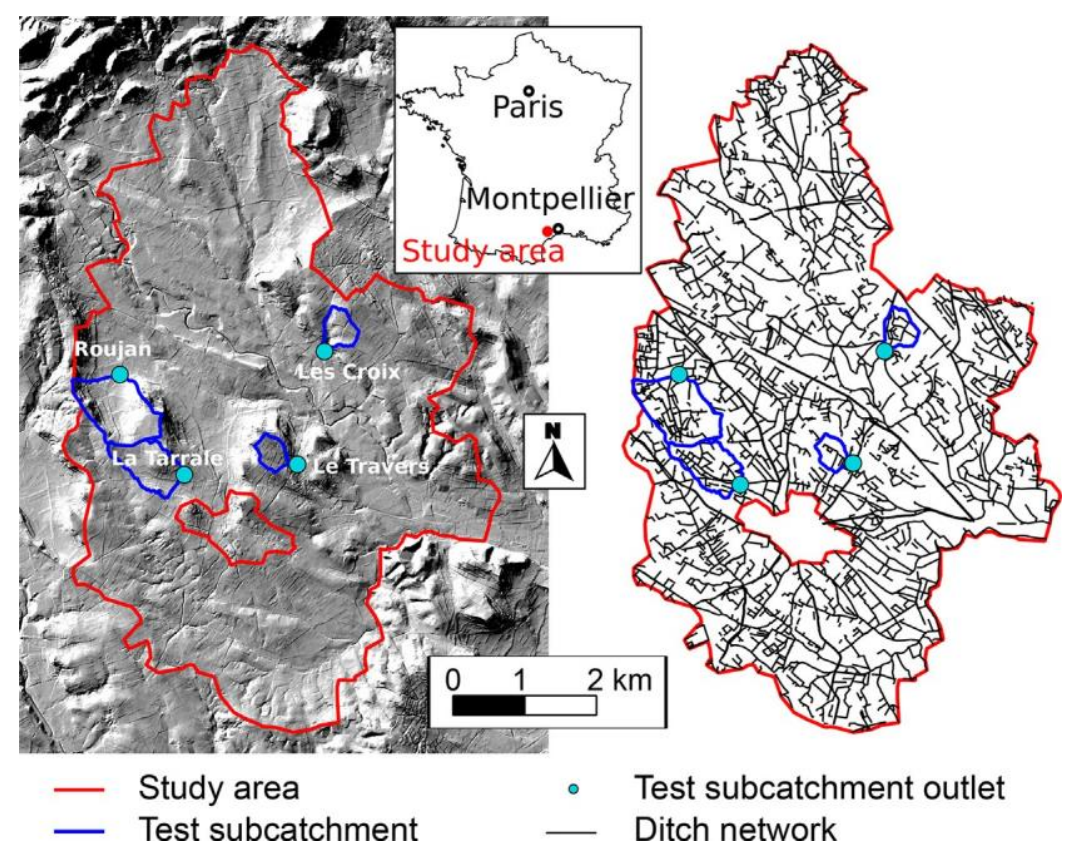

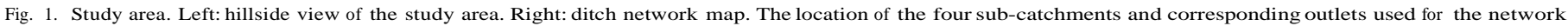
simulation.

As pressures from the market continue to increase, the search for a good compromise between these costs and the efficiency of measures for protecting soils from erosion is accelerating (Douglas et al., 1996). Tarolli et al. (2015) proposed a morphometric index derived from LiDAR as a support for scheduling a correct ditch network to reduce erosion. In their work they proposed only a few simple examples of different ditch systems. To extent this approach, numerical experiment can be proposed to explore the effects of a wide range of ditch network geometries on soil erosion. In this case, numerical experiment consists in coupling a soil conservation features simulator and an erosion model. It has been successfully used by Gumiere et al. (2015) to optimise the location of vegetative filters regarding their efficiency in reducing erosion.

This paper proposes a numerical experiment-based approach that tests actual soil conservation practices for their closeness to a cost-efficiency compromise. This approach is applied to the ditch networks of the Languedoc vineyard catchments (Levavasseur et al., 2014). In this experiment, the costs are approximated based on the densities of the ditches, and the rill erosion risks are summarised by a modified stream power index (Moore et al., 1991). In four small sub-catchments located in the Peyne catchment (Languedoc - southern France), the actual ditch networks are compared to a set of virtual networks that are produced by a network simulation algorithm that browses a large range of densities and optimises the network geometries with regard to rill erosion protection. Finally, the approach is completed by quantifying the role of the ditch network in reducing erosion over the entire Peyne catchment.

\section{Study area}

\subsection{Main characteristics}

The study area is located in the downstream portion of the Peyne catchment in southern France (Fig. 1, left), which covers an area of $40 \mathrm{~km}^{2}$ and is mainly covered by vineyards (60\%) with shrubs, cereal fields and fallow fields occupying the remaining areas. The average field area is approximately 0.5 ha. The altitude varies between $28 \mathrm{~m}$ and $128 \mathrm{~m}$, and three main geomorphological units can be distinguished, plateaus in the southern and northwestern areas, hill-slopes with slopes greater than $10 \%$ in the centre of the area and an alluvial plain. The climate is Mediterranean with an annual precipitation of $600 \mathrm{~mm}$ to $800 \mathrm{~mm}$ and two short, intense rainy seasons in the autumn and spring. Given the characteristics of the catchment, soil erosion can be high, with an average erosion rate of $10.5 \mathrm{t} / \mathrm{ha} / \mathrm{y}$ and a high spatial variability (Paroissien et al., 2010). Four headwater sub-catchments were selected within the study area (Fig. 1, right) for hosting the numerical experiments. These catchments have various areas, slopes, land cover and ditch network densities (Table 1).

\subsection{Ditch networks}

The ditch network of the study area was exhaustively mapped during previous studies (Bailly and Levavasseur, 2012; Levavasseur et al., 2012, 2014). The width and depth of the ditches varied from approximately $50 \mathrm{~cm}$ to several meters. The mean density of the ditch networks was $96 \mathrm{~m} / \mathrm{ha}$. The minimum and maximum values of the ditch network density, calculated using $250 \mathrm{~m} \times 250 \mathrm{~m}$ pixels, were $0 \mathrm{~m} / \mathrm{ha}$ and $231 \mathrm{~m} / \mathrm{ha}$, respectively. This ditch network mainly consisted of agricultural and roadside ditches, but also included sunken paths and channelised rivers that were considered as 'ditches' for simplification. In the Languedoc vineyard plain, the ditch networks are often associated with terraces and were built over a century ago to remove excess water from fields and eliminate the highly visible threat of rill erosion. This assumption was recently confirmed by surveying farmers in the study area (Levavasseur, 2012), which indicated that $50 \%$ of the ditches were perceived as erosion-limiting landscape features and $80 \%$ of the ditches were declared as being yearly maintained for preventing the overflow that generates rill erosion. This driver is clearly illustrated in Fig. 2 for a particular event.

\subsection{Spatial data}

Three types of spatial data were involved in the proposed approach. (i) A stereo-photogrammetric $5 \mathrm{~m}$ resolution Digital 
Table 1

Characteristics of the four sub-catchments.

\begin{tabular}{|c|c|c|c|c|}
\hline Name & Area (ha) & Mean slope (\%) & Land cover & $\begin{array}{l}\text { Ditch network } \\
\text { density }(\mathrm{m} / \mathrm{ha})\end{array}$ \\
\hline Roujan & 91 & 8 & $\begin{array}{l}\text { Agriculture: } 83.7 \% \\
\text { Natural areas: } 13.9 \% \\
\text { Roads: } 1.4 \% \\
\text { Tracks: } 1.0 \%\end{array}$ & 110 \\
\hline La Tarrale & 55 & 4 & $\begin{array}{l}\text { Agriculture: } 94.6 \% \\
\text { Natural areas: } 3.5 \% \\
\text { Roads: } 1.7 \% \\
\text { Tracks: } 0.3 \%\end{array}$ & 126 \\
\hline Les Croix & 24 & 7 & $\begin{array}{l}\text { Agriculture: } 97.5 \% \\
\text { Natural areas: } 1.1 \% \\
\text { Roads: } 1.1 \% \\
\text { Tracks: } 0.4 \%\end{array}$ & 119 \\
\hline Le Travers & 18 & 5 & $\begin{array}{l}\text { Agriculture: } 91.3 \% \\
\text { Natural areas: } 4.2 \% \\
\text { Roads: } 1.2 \% \\
\text { Tracks: } 1.3 \% \\
\text { Residential: } 2.0 \%\end{array}$ & 87 \\
\hline
\end{tabular}

Elevation Model (DEM) provided by the local government. Preprocessing was applied to this DEM to remove sinks and ensure continuous water flow paths (Wang and Liu, 2006). (ii) The lattices of the field boundaries that were digitised from an airborne image of the study area were acquired in 2007. (iii) A $5 \mathrm{~m}$ resolution land use map with a simple classification (agriculture, natural area, track, or road) was obtained by visually interpreting the image evoked above.
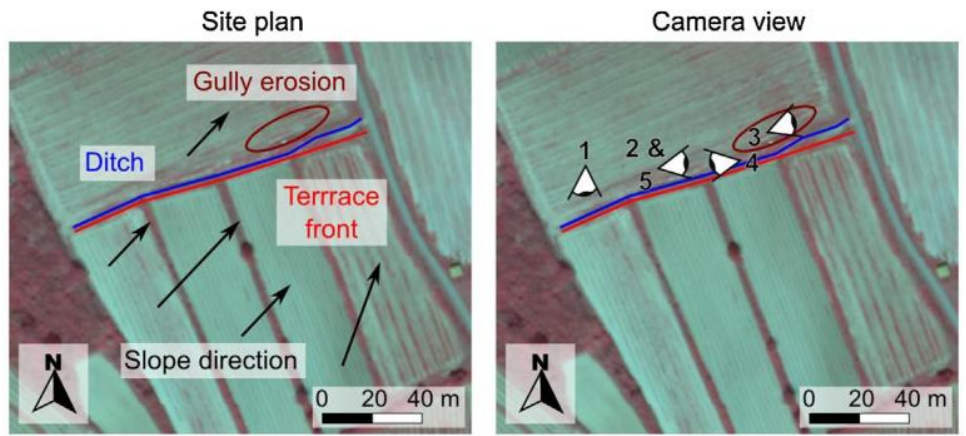

March 3rd, 2011: a filled ditch and gully erosion during a rain event

Picture 1

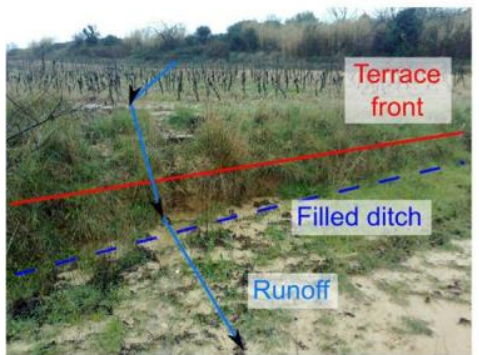

Picture 2

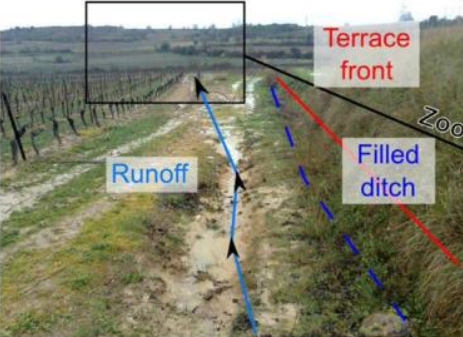

Picture 3

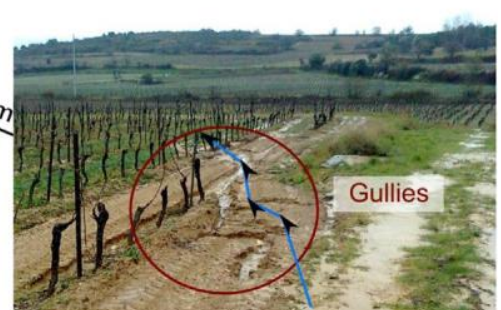

April 29th, 2011: ditch has been dredged

Picture 4

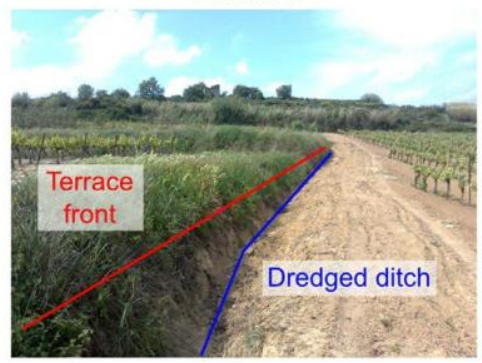

Picture5

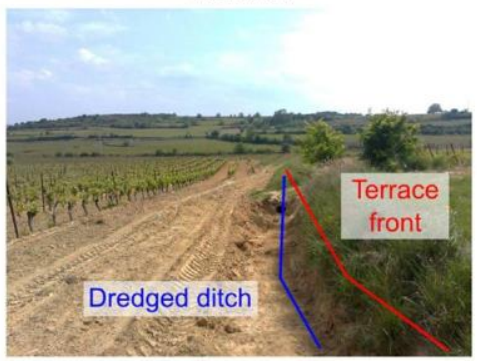

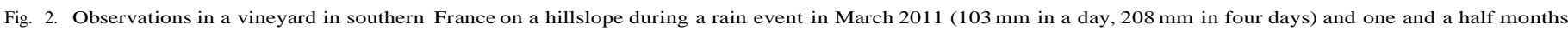

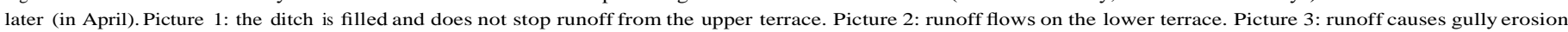
on the lower terrace. Pictures 4 and 5: one and a half months later, the ditch was dredged and could intercept runoff. 


\section{a}

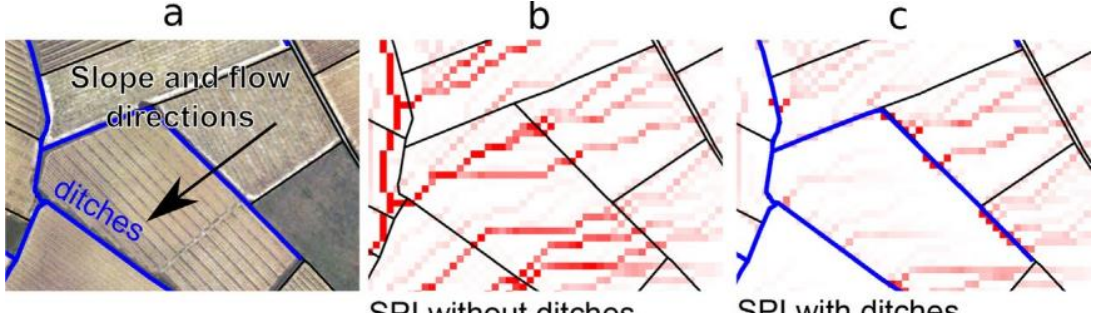

SPI without ditches

SPI with ditches

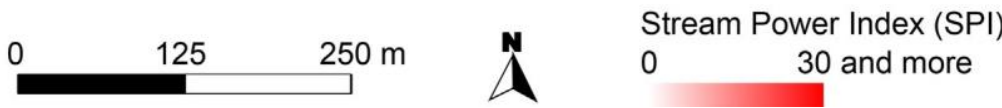

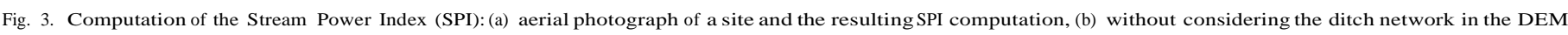
or (c) when burning the ditch network in the DEM.

\section{Methods}

The general principle of the proposed approach is to compare the geometry of the actual ditch network with the geometries of many

other possible ditch networks (Levavasseur et al., 2012) regarding their abilities to mitigate rill erosion. Thus, this approach requires (i) an indicator for quantifying rill erosion risks for a given ditch net-

work, (ii) an algorithm that simulates ditch networks over a large range of densities and spatial configurations and (iii) a protocol for setting the numerical experiment on a given catchment. These three points are detailed below.

\subsection{Rill erosion risk assessment}

The risk or rill erosion was evaluated using a modified version

of the Stream Power Index (SPI) that has been widely used for mapping soil erosion risks where soil conservation practices should be implemented (Moore et al., 1991). The SPI at a given location was expressed as follows:

$\mathrm{SPI}=\mathrm{kA} \times \tan ^{\smile}$

where SPI is the Stream Power Index, $\smile$ is the slope, and A is the upstream drained area. The k coefficient was introduced to account for possible water infiltration in the upstream drained area, which attenuate the soil erosion risks. This coefficient varies between 0 and 1 according to the land use of the upstream drained area. First, we calculated the SPI at each pixel of a modified $5 \mathrm{~m}$ resolution DEM that was obtained by burning the ditch network in the initial DEM. Burning was performed by decreasing the elevation value at each pixel overlapping the ditch network (Saunders, 1999). The slope was computed as the first derivative of the elevation from an adjusted polynomial surface formed by 3 by 3 windows centred on the pixel (Zevenbergen and Thorne, 1987). The upstream drained area was computed as the area of the catchment with the pixel as the outlet. According to previous hydrological modelling studies that were conducted in the same area (Moussa et al., 2002; Chahinian, 2004), the $\mathrm{k}$ values were fixed at $1,1 / 5,1 / 15$ and $1 / 80$ for the pixels that mainly included roads, tracks, cultivated areas and natural areas, respectively.

Fig. 3 illustrates the impacts of ditch networks on the computation of the SPI on a hillslope (Fig. 3a). Without the ditch network (Fig. 3b), runoff is concentrated along the hillslope, which results in high SPI values within the fields (red pixels). Conversely, when the ditch network was present (Fig. 3c), the ditches intercepted runoff and resulted in low SPI values (white pixels).
Next, the SPI was successively upscaled to field and catchment scales using spatial aggregations of the SPI values. Upscaling to the field scale was performed as follows:

$$
\mathrm{SPI}_{\mathrm{j}}={ }_{\mathrm{n}} \times \mathrm{SPI}_{\mathrm{i}}
$$

where $\mathrm{SPI}_{\mathrm{j}}$ is the mean SPI value of field $\mathrm{j}, \mathrm{SPI}_{\mathrm{i}}$ is the SPI value of pixel $i$ located in field $\mathrm{j}$, and $\mathrm{n}$ is the number of pixels in field $\mathrm{j}$. To avoid boundary and rasterisation effects, the pixels located less than $5 \mathrm{~m}$ from a field boundary were excluded from this aggregation process. Next, the SPI was upscaled to the catchment scale by aggregating the field SPI values $\left(\mathrm{SPI}_{j}\right)$ as follows:

$\mathrm{SPI}_{\mathrm{k}}=\frac{1}{{ }_{\mathrm{j}} \mathrm{A}_{\mathrm{j}}} \times \quad \mathrm{SPI}_{\mathrm{j}} \times \mathrm{A}_{\mathrm{j}}$

where $\mathrm{SPI}_{k}$ is the aggregated SPI value of sub-catchment $\mathrm{k}, \mathrm{A}_{\mathrm{j}}$ is the area of field $\mathrm{j}$ in sub-catchment $\mathrm{k}$, and $\mathrm{SPI}_{\mathrm{j}}$ is the mean SPI values of cultivated field $\mathrm{j}$ in sub-catchment $\mathrm{k}$. Because we focused on the rill erosion perceived by farmers, this aggregation was restricted to cultivated fields.

\subsection{Simulation of the ditch networks}

A previously developed simulation ditch networks algorithm (SDNA) (Bailly et al., 2011) was adapted to account for the rill erosion risks. In the following section, we summarise the main characteristics of the basic algorithm and describe the modifications that were performed. Additional details can be found in Bailly et al. (2011).

When using the SDNA, it is assumed that the ditches are located at the field boundaries. The ditch networks are thus represented by connected and directed sub-graphs of the planar lattice that represent the cultivated field boundaries within a cultivated landscape. The role of the SDNA is to select whether each lattice element is a ditch or not according to a stochastic drainage process. The initial SDNA builds tree-structured sub-graphs with a defined root (the outlet of the catchment) and a set of disconnected reaches that should be known. It performs the connexion between disconnected reaches and the outlet while (i) accounting for the slope direction of each lattice elements, (ii) considering a given network length (or a drainage density) and (iii) maximising the proportions of the reconnected reaches. This algorithm uses random network initialisation and a simulated annealing algorithm, which are both based on random pruning or branching processes, to converge the multiobjective properties of the networks. Thus, the following steps are used to build a set of possible ditch networks: valuation of the planar lattice of the field boundaries by the slope directions obtained 


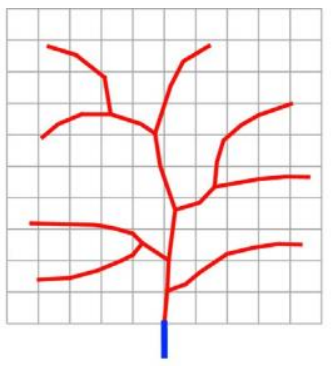

Initialization

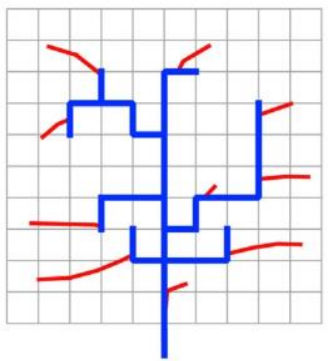

Simulated ditch network after $\mathrm{k}$ iterations

Field boundaries lattice High SPI value

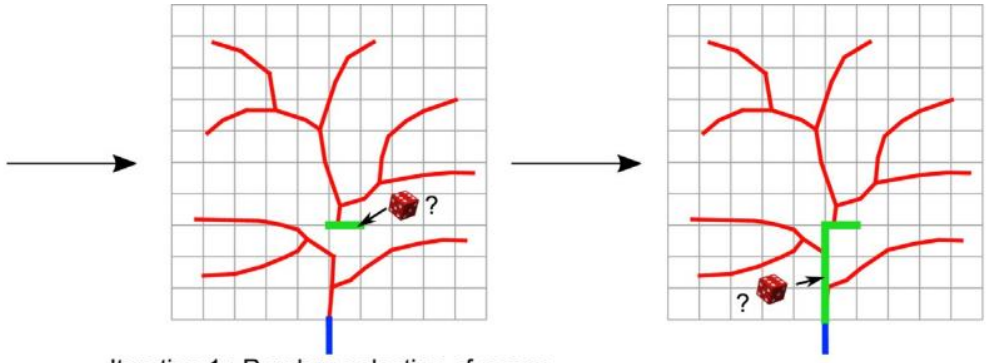

Iteration 1 : Random selection of a new disconnected ditch with a high SPI value

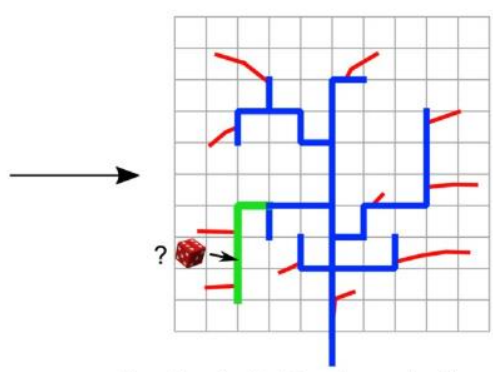

Iteration $\mathrm{k}+1$ : Random selection of a new disconnected ditch with a high SPI value and random branching

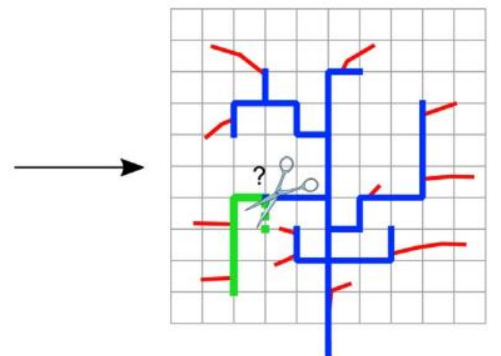

Iteration $\mathrm{k}+1$ : Random pruning of a ditch became useless (low SPI value)

Simulated network before iteration Added segment during iteration

Fig. 4. Conceptual diagram of the modified simulation ditch network algorithm.

from a DEM (step 1), selection of an outlet among the lattice nodes and of known reaches among the lattice edges (step 2), running the branching/pruning processes until the target network length is attained (step 3), and saving the resulting ditch network (step 4). Steps 3 and 4 are iterated until the required number of possible ditch networks is produced. The erosion-adapted SDNA differs from the basic SDNA when considering the maximum SPI value calculated at each edge of the lattice representing the field boundaries (Fig. 4). This value is used in step 2 to select the initial disconnected reaches among the reaches with the greatest SPI values (i.e., that best minimise rill erosion risks). In addition, this value is used in step 3 to orient the addition or deletion of ditches on the lattice edges through the branching/pruning process. For example, a ditch that becomes useless (low SPI value) following the addition of an other ditch upstream is removed during the pruning process.

Because the tree sub-graph geometry is constantly modified during this process, the SPI must be recalculated for each lattice edge at each iteration, which significantly increases the computing time relative to the basic SDNA. This algorithm was developed in R using the RSAGA library (Brenning, 2008). For example (Fig. 5), it took $15 \mathrm{~min}$ to produce a set of 3 ditch networks representing between 30 and 300 reaches in a $1 \mathrm{~km}^{2}$ sub-catchment when using a usual $2 \mathrm{GHz}$ dual core PC.

\subsection{Numerical experimental design}

A set of 100 possible ditch networks was generated for each of the four studied sub-catchments. For a given sub-catchment, the target network lengths (i.e., densities) were randomly selected between the length of the outlet segment (a few decametres) and the cumulative length of the field boundaries (up to $30,000 \mathrm{~m}$ per $\mathrm{km}^{2}$ ). However, the sampling favoured small lengths (i.e., the two first terciles) to better explore the larger spaces of the possible networks when the small lengths were imposed. Assuming homogeneous ditch building costs and the costs of maintaining the ditches for a specified length, the costs of the ditch network at the sub-catchment scale mainly varied with the densities of the networks (i.e., the length of the ditch network).

Each of the simulated ditch networks was evaluated for its ability to mitigate erosion using the catchment-pooled SPI presented above. Finally, the erosion mitigation that resulted from the actual ditch networks of the four sub-catchments was compared with the simulated networks, allowing a Pareto optimality frontier delineation into the network density and erosion risk space. Because it was not possible to apply this numerical experiment throughout

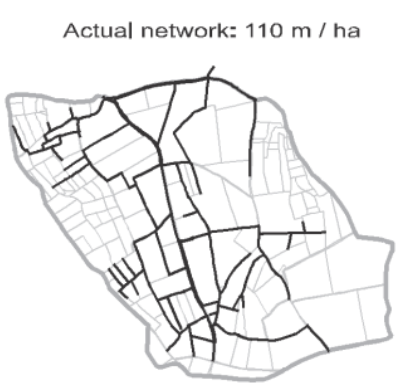

SImulated network: $57 \mathrm{~m} / \mathrm{ha}$

Simulated network: $117 \mathrm{~m} / \mathrm{ha}$
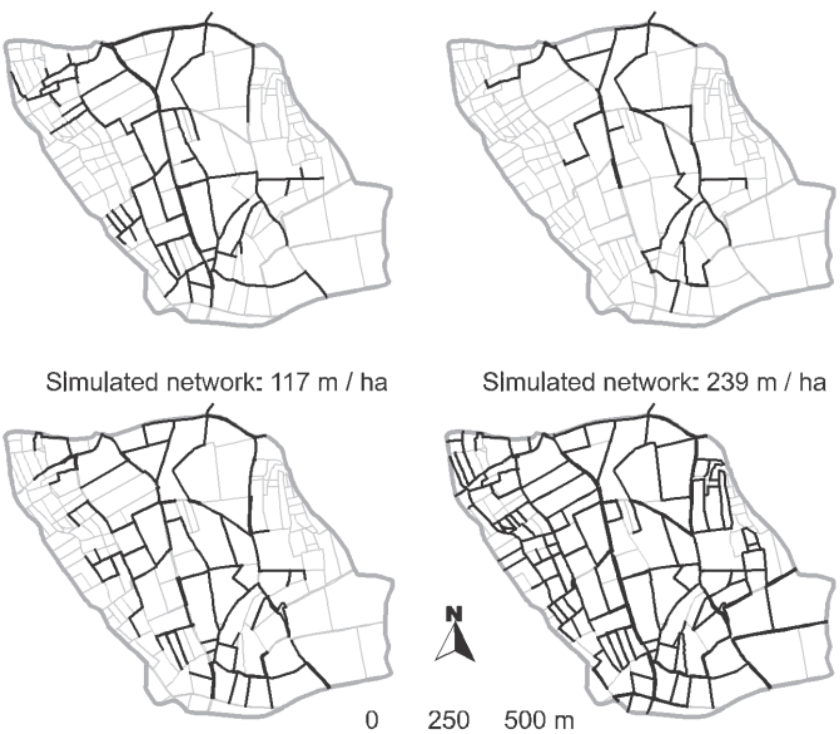

Simulated network: $239 \mathrm{~m} / \mathrm{ha}$

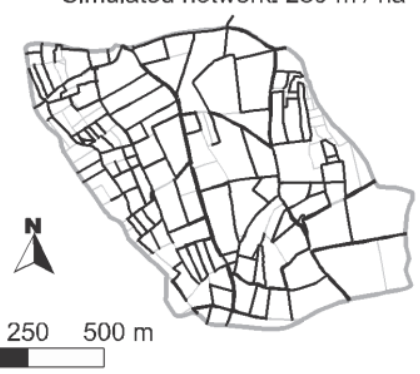

— Dltches

Fleld boundarles

Catchment boundary

Fig. 5. The actual ditch network of the Roujan sub-catchment and three example simulated ditch networks with contrasting network densities. 

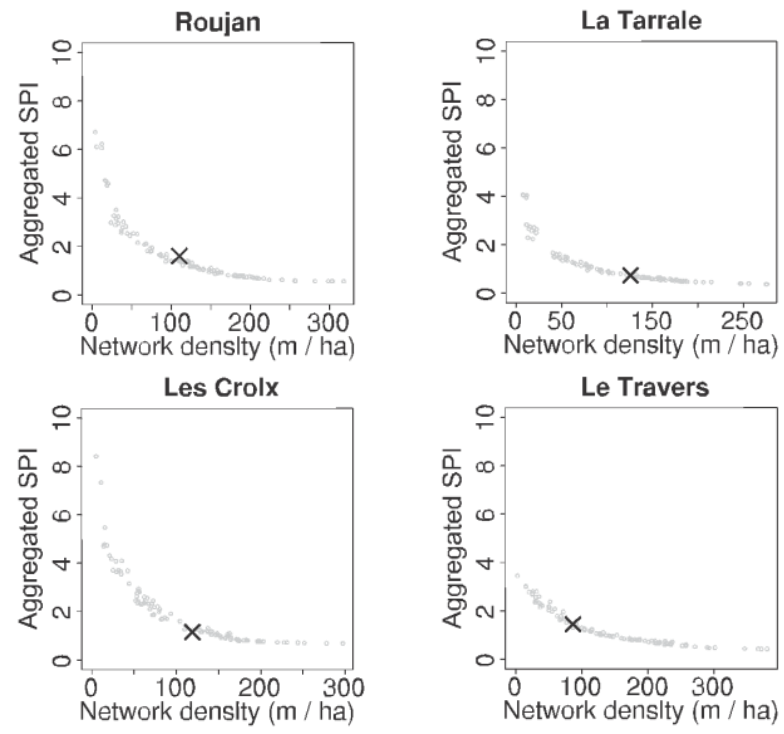

Fig. 6. Relationships between the aggregated SPI and ditch network lengths depending on the version of the network simulator for the four sub-catchments.

the drainage network of the Peyne catchment due to computing limitations, a simplified approach that avoided the simulation step was used to obtain complementary results at this scale. This approach consisted of computing the aggregated SPI values (Eq. (3)) on a $250 \mathrm{~m}$ square grid that covered the entire study area. These values were calculated with and without considering the actual ditch networks and were compared to each other.

\section{Results}

\subsection{Network length vs rill erosion}

The lengths of the simulated ditch networks were plotted against the sub-catchment-aggregated SPI (Fig. 6). Clear exponential decreases in the SPI were observed in all the studied sub-catchments. The reduced erosion rate measured by the SPI was greater for the smallest lengths and became negligible beyond the thresholds of the network length, ranging from 100 to $200 \mathrm{~m} / \mathrm{ha}$. The minimal SPI values were low and rather similar across the subcatchments (between 0 and 1), and larger variations were observed across the catchments for the smallest network lengths (between 3.5 and 6.5 ).

4.2. Performances of the actual sub-catchment ditch networks for mitigating erosion

Regardless of the sub-catchment, the abilities of the actual ditch networks to mitigate rill erosion, as measured by the SPI, were similar and near the maximum (minimum SPI) that was obtained by the simulations (Fig. 6). However, the minimal simulated SPI values in Roujan and Le Travers were slightly greater than those observed in la Tarrale and Les Croix. For all sub-catchments other than Roujan, these SPI values were obtained when using ditch network lengths that were similar to the lengths optimised by the erosion-adapted SDNA (near the approximated Pareto frontier), which meant that these ditch networks were optimal with regard to erosion mitigation. Conversely, in Roujan, a simulated network yielded a SPI similar to that of the actual network with a length that was $30 \%$ less than that of the actual one ( $77 \mathrm{~m} / \mathrm{ha}$ vs $110 \mathrm{~m} / \mathrm{ha})$.

\subsection{Extension to the Peyne catchment}

Fig. 7 shows the maps of the aggregated SPI values on a $250 \mathrm{~m}$ grid across the entire Peyne catchment with and without considering the actual ditch network (Fig. 7a and $7 \mathrm{~b}$ respectively). Fig. 7a exhibited large variations in the SPI that were governed by variations in relief and land use within the catchment. When the impact of the ditch network was considered (Fig. 7b), the mapped SPI values decreased dramatically and were less variable, as the tail of the high SPI values observed in Fig. 7a decreased. This finding confirmed the results obtained on the four studied sub-catchments (SPI for lowest and greatest values of drainage density on Fig. 6).

\section{Discussion}

\subsection{Diagnosis of the actual ditch networks with regard to rill} erosion

The results obtained from the four studied sub-catchments and from the entire Peyne catchment showed that the ditch networks played a major role in limiting the risks of rill erosion in cultivated fields because the SPI values dramatically decreased and became homogeneous when the actual ditch networks were considered. Furthermore, we showed that mitigation of the rill erosion risk was obtained for minimal drainage networks lengths in four sub-catchments, which suggests that the actual ditch network geometries resulted from an optimisation process conducted by farmers over the centuries. This highlights the importance of erosion mitigation as the first priority when building ditches in Mediterranean cultivated landscapes (Ramos and Porta, 1997; Roose and Sabir, 2002; Gardner and Gerrard; Paroissien et al., 2010; Stanchi et al., 2012). For further confirmation, the actual and simulated ditch networks were compared within a bivariate Pareto frontier optimality framework to determine whether the efficiency of ditch networks for mitigating erosion could be improved. Based on this comparison, the Les Croix and La Tarralle sub-catchments already appear fully optimised, i.e., located on the Pareto frontier. In the Le Travers sub-catchment, the ditch network density appears to be optimised regarding the rate of protection against erosion. However, this rate could decrease for a denser network. In the Roujan sub-catchment, the simulated ditch networks with densities that were similar to the actual densities showed lower SPI values, which suggested that a better geometry could result in better erosion protection. However, this apparent non-optimality may also result from the need to optimise the ditch network for another landscape function, such as groundwater drainage (see further discussion). Additional studies are necessary to understand why these two sub-catchments only exhibited sub-optimal ditch networks.

\subsection{Erosion modelling limitations}

In the proposed approach, the risks of rill erosion were modelled using the SPI, which was further aggregated for sub-catchments $(250 \mathrm{~m} \times 250 \mathrm{~m}$ pixels $)$. The simplicity of this index was advantageous for building a new version of the network simulator that produced optimised ditch networks for mitigating erosion. However, the SPI only considers the local relief, upstream land use and the presence of run-off interception features and does not consider soil and climate variabilities, which may generate bias in erosion risk assessments. However, recent studies in the same region (Paroissien et al., 2010) indicated that the relief (slope) and ditches were the first features that explained multi-decennial erosion in vineyards, which confirmed the value of using SPI in this region. The extension of this method to other landscapes would likely require the use of more sophisticated approaches for 


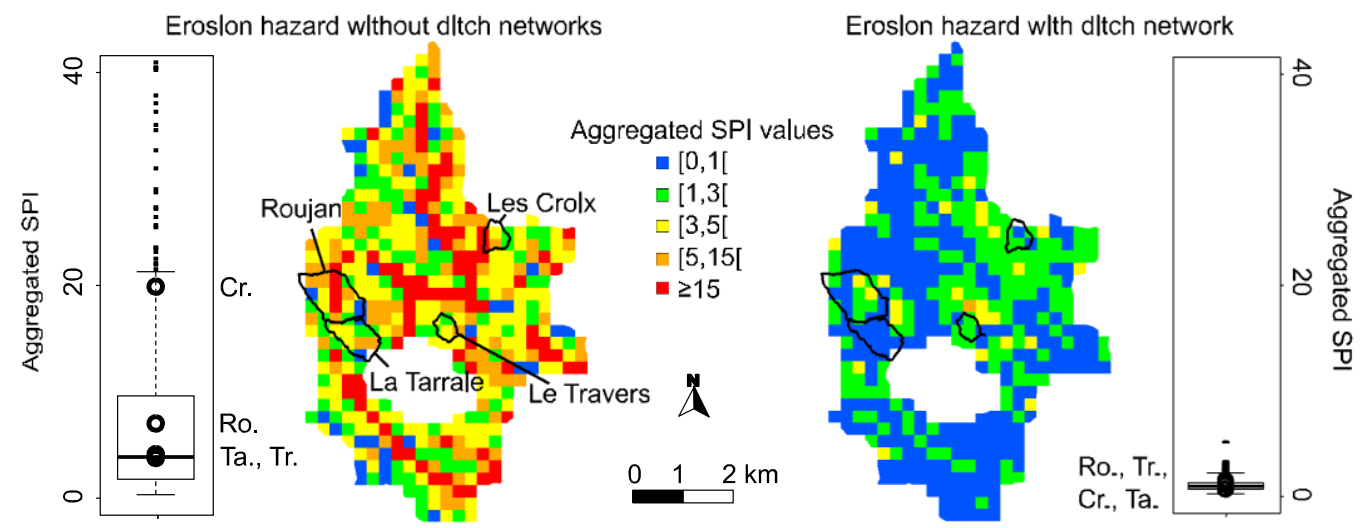

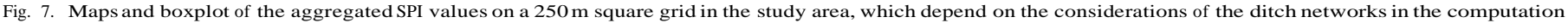
of the SPI.

assessing erosion, such as physically-based and spatially explicit erosion models, e.g., EUROSEM (Morgan et al., 1998) or MhydasErosion (Gumiere et al., 2011). Nevertheless, some parameter calibration issues occur when using these models (Hessel and Tenge, 2008) that would require undertaking more field observations (Bellin et al., 2009). Furthermore, computational solutions should be found for coupling these models with the presented network simulator while maintaining reasonable computing costs.

\subsection{Extending to other soil conservation features}

Our approach only considered building ditches as unique soil conservation practices, for which several soil conservation practices are usually combined (e.g., building terraces and ditches) (Ramos and Porta, 1997; Stanchi et al., 2012). The presence of terraces was partially considered by using a high resolution $(5 \mathrm{~m})$ DEM. However, changes in terrace locations were not considered in our simulation algorithm. Further investigations should (i) include the simulation algorithm and the entire set of possible soil conservation features (ditches, terraces, embankments, grass strips, etc.) with their specific constraints and spatial relationships to each other and (ii) represent their impacts on erosion, which can be used for more sophisticated models than the SPI (see above).

\subsection{Multifunctional role of the ditch networks}

This study focused on the roles of ditch networks in mitigating rill erosion in fields. Because ditches are involved in many landscape processes, they have many other functions and impacts that should be considered in a comprehensive evaluation. First, ditches can be made for purposes other than erosion mitigation (e.g., draining groundwater, conducting excess water). Furthermore, they have secondary impacts, such as impacts on ditch-edge erosion (Elliot and Tysdal, 1999), flood intensification in downstream areas (Moussa et al., 2002; Roose and Sabir, 2002; Buchanan et al., 2013), groundwater recharge concentrations(Dages et al., 2009), pesticide mitigation (Stehle et al., 2011) and biodiversity control (Herzon and Helenius, 2008). Thus, it is highly probable that ditch networks may not be equally optimal across all these aspects, especially regarding the unintended impacts other than rill erosion mitigation. Next, a multi-criteria analysis should be conducted, which requires extending the proposed approach to many other landscape processes.

\subsection{Towards structure-function numerical experiments}

These numerical experiments conducted to assess the efficiency of ditch networks for mitigating rill erosion in the Languedoc vineyard could serve as a starting point for future studies involving 'structure-function-value' chains, which are advocated by Termorshuizen and Opdam (2009) for dealing with landscape services. Comparisons between the actual spatial structures of the landscape features and the simulated potential features regarding several landscape function indicators should provide landscape managers with a method for diagnosing actual landscape structures and for exploring improved solutions based on quantitative assessments, such as those presented in Fig. 6. In addition, this study should be communicated to a wide range of people to communicate the modelling results, which are not frequently considered in decision making regarding landscape planning.

\section{Conclusions}

This paper proposed an experimental numerical approach for testing how an actual ditch network on a catchment, which is viewed as a soil conservation practice, is efficient for mitigating rill erosion regarding its costs. The costs were determined according to the density of ditches, and the rill erosion mitigation efficiency was measured at the catchment scale by aggregating stream power indices from cultivated plots. This method builds a ditch densityerosion mitigation efficiency relationship using a ditch network stochastic simulator that was specifically designed for rill erosion. In addition, this method requires a DEM, a land-use map, a map of the cultivated plot boundaries and a map of the actual ditch network and outlet locations.

Finally, this method was applied to four small and contrasting vineyard catchments located in the Languedoc vineyard in southern France. A set of 100 virtual ditch networks with various ditch densities were generated on each of the four sub-catchments. The actual ditch network locations were compared to the virtual network locations based on the ditch density-erosion mitigation efficiency relationships.

Overall, the results indicated that ditch networks highly mitigate the threat of rill erosion because the stream power index values decrease exponentially with the ditch network density. In addition, the results from the four contrasted sub-catchments in this study indicated that the mitigation of rill erosion risk was obtained using minimal drainage network lengths, suggesting that the actual ditch networks resulting from historical farmers are already optimised. This finding is re-enforced when comparing networks at the Peyne catchment scale using the stream power index maps with a resolution of $250 \mathrm{~m}$ and considering or not considering the actual ditch networks. For the former map, the rill erosion mitigation efficiency is high (low SPI values) and homogeneous, regardless of the topography, the land-cover and the ditch network density. 
The proposed approach allows users to diagnose whether the efficiency of a soil conservation technique for preventing erosion (e.g., ditch networks) can be improved. In the future, this experiment should be extended to others soil conservation features (e.g., terraces). A multifunctional approach should also be favored in order to take into account side-effects of these soil conservation features.

\section{Acknowledgements}

This work was partly supported by funds for a $\mathrm{PhD}$ thesis provided by the region of Languedoc-Roussillon. The authors thank the Conseil Général de l'Hérault for providing the DTM data.

\section{Appendix A. Supplementary data}

Supplementary data associated with this article can be found, in the online version, at http://dx.doi.org/10.1016/j.landusepol.2015. 08.033. These data include Google maps of the most important areas described in this article.

\section{References}

Bailly, J.S., Levavasseur, F., 2012. Potential of linear features detection in a Mediterranean landscape from 3D VHR optical data: application to terrace walls. In: IGARSS, Munich, Germany, July 22-27, pp. 7110-7113, http://dx.doi.org/10. 1109/IGARSS.2012.6352024.

Bailly, J.S., Levavasseur, F., Lagacherie, P., December 2011. A spatial stochastic algorithm to reconstruct artificial drainage networks from incomplete network delineations. Int. J. Appl. Earth Obs. Geoinf. 13 (6), 853-862, http://dx.doi.org/ 10.1016/j.jag.2011.06.001, ISSN 0303-2434.

Bellin, N., van Wesemael, B., Meerkerk, A., Vanacker, V., Barbera, G.G., 2009. Abandonment of soil and water conservation structures in Mediterranean ecosystems: a case study from south east Spain. CATENA 76 (January (2)), 114-121, http://dx.doi.org/10.1016/j.catena.2008.10.002.

Bevan, A., Conolly, J., 2011. Terraced fields and Mediterranean landscape structure: an analytical case study from Antikythera, Greece. Ecol. Model. 222 (7), 1303-1314, http://dx.doi.org/10.1016/j.ecolmodel.2010.12.016, ISSN 03043800 .

Blondel, J., 2006. The design of Mediterranean landscapes: a millennial story of humans and ecological systems during the historic period. Hum. Ecol. 34 (5), 713-729, http://dx.doi.org/10.1007/s10745-006-9030-4.

Brenning, A., 2008. Statistical geocomputing combining R and SAGA: the example of landslide susceptibility analysis with generalized additive models. In: Boehner, J., Blaschke, T., Montanarella, L. (Eds.), SAGA - Seconds Out (= Hamburger Beitraege zur Physischen Geographie und Landschaftsoekologie, vol. 19)., pp. 23-32.

Buchanan, B.P., Falbo, K., Schneider, R.L., Easton, Z.M., Walter, M.T., 2013. Hydrological impact of roadside ditches in an agricultural watershed in central New York: implications for non-point source pollutant transport. Hydrol. Process. 27 (17), 24372422, http://dx.doi.org/10.1002/hyp.9305.

Chahinian, N., 2004. Paramétrisation multi-critère et multi-échelle d'un modèle hydrologique spatialisé de crue en milieu agricole (Ph.D. thesis). Université Montpellier II.

Dages, C., Voltz, M., Bsaibes, A., Prévot, L., Huttel, O., Louchart, X., Garnier, F., Negro, S., 2009. Estimating the role of a ditch network in groundwater recharge in a Mediterranean catchment using a water balance approach. J. Hydrol. 375 (3), 498-512, http://dx.doi.org/10.1016/j.jhydrol.2009.07.002

Douglas, T., Critchley, D., Park, G., 1996. The deintensification of terraced agricultural land near Trevelez, Sierra Nevada, Spain. Glob. Ecol. Biogeogr. Lett. 25, 8-270.

Elliot, W.J., Tysdal, L.M., 1999. Understanding and reducing erosion from insloping roads. J. For. 97 (8), 30-34.

Gardner, R.A.M., Gerrard, A.J., 2003. Runoff and soil erosion on cultivated rainfed terraces in the middle hills of Nepal. Appl. Geogr. 23 (January (1)), 23-45, http:// dx.doi.org/10.1016/S0143-6228(02)00069-3.

Gumiere, S., Bailly, J.S., Cheviron, B., Raclot, D., Le Bissonnais, Y., Rousseau, A., 2015. Evaluating the impact of the spatial distribution of land management practices on water erosion: case study of a Mediterranean catchment. J. Hydrol. Eng. 20 (6), C5014004, http://dx.doi.org/10.1061/(ASCE)HE.1943-5584.0001076, ISSN 1084-0699.

Gumiere, S.J., Raclot, D., Cheviron, B., Davy, G., Louchart, X., Fabre, J.C., Moussa, R., Le Bissonnais, Y., 2011. MHYDAS-Erosion: a distributed single-storm water erosion model for agricultural catchments. Hydrol. Process. 25 (11), 1717-1728, http:// dx.doi.org/10.1002/hyp.7931

Herzon, I., Helenius, J., 2008. Agricultural drainage ditches, their biological importance and functioning. Biol. Conserv. 141 (5), 1171-1183, http://dx.doi.org/10. 1016/j.biocon.2008.03.005.

Hessel, R., Tenge, A., 2008. A pragmatic approach to modelling soil and water conservation measures with a catchment scale erosion model. CATENA 74 (2), 119-126, http://dx.doi.org/10.1016/j.catena.2008.03.018.

Levavasseur, F., 2012. Structure du paysage et fonctionnement hydrologique. Application aux réseaux de fossés en zone viticole méditerranéenne (Ph.D. thesis). Montpellier Supagro - École Doctorale SIBAGHE.

Levavasseur, F., Bailly, J.S., Lagacherie, P., Colin, F., Rabotin, M., 2012. Simulating the effects of spatial configurations of agricultural ditch drainage networks on surface runoff from agricultural catchments. Hydrol. Process. 16 (22), 3393-3404, http://dx.doi.org/10.1002/hyp.8422.

Levavasseur, F., Lagacherie, P., Bailly, J.S., Biarnès, A., Colin, F., 2014. Spatial modeling of man-made drainage density of agricultural landscapes. J. Land Use Sci., http:// dx.doi.org/10.1080/1747423X.2014.884644.

Martnez-Casasnovas, J.A., Ramos, M.C., 2006. The cost of soil erosion in vineyard fields in the Penedès - Anoia region (NE Spain). CATENA 68 (23), 194-199, http:// dx.doi.org/10.1016/j.catena.2006.04.007.

Moore, I.D., Grayson, R.B., Ladson, A.R., 1991. Digital terrain modelling: a review of hydrological, geomorphological, and biological applications. Hydrol. Process. 5 (1), 330, http://dx.doi.org/10.1002/hyp.3360050103.

Morgan, R.P.C., Quinton, J.N., Smith, R.E., Govers, G., Poesen, J.W.A., Auerswald, K., Chisci, G., Torri, D., Styczen, M.E., 1998. The European soil erosion model (EUROSEM): a dynamic approach for predicting sediment transport from fields and small catchments. Earth Surf. Process. Landf. 23 (6), 527544, http://dx.doi. org/10.1002/(SICI) 1096-9837(199806)23:6<527::AID-ESP868>3.0.CO;2-5.

Moussa, R., Voltz, M., Andrieux, P., 2002. Effects of the spatial organization of agricultural management on the hydrological behaviour of a farmed catchment during flood events. Hydrol. Process. 16 (2), 393-412, http://dx.doi.org/10.1002/hyp. 333.

Nasri, S., 2007. Caractéristiques et impacts hydrologiques de banquettes en cascade sur un versant semi-aride en Tunisie centrale/characteristics and hydrological impacts of a cascade of bench terraces on a semi-arid hillslope in central Tunisia. Hydrol. Sci. J. 52 (6), 1134-1145, http://dx.doi.org/10.1623/hysj.52.6.1134, ISSN 0262-6667.

Paroissien, J.B., Lagacherie, P., Le Bissonnais, Y., 2010. A regional-scale study of multi-decennial erosion of vineyard fields using vine-stock unearthing-burying measurements. CATENA 82 (September (3)), 159-168, http://dx.doi.org/10. 1016/j.catena.2010.06.002.

Petanidou, T., Kizos, T., Soulakellis, N., 2008. Socioeconomic dimensions of changes in the agricultural landscape of the Mediterranean basin: a case study of the abandonment of cultivation terraces on Nisyros Island, Greece. Environ. Manage. 41 (2), 250-266, http://dx.doi.org/10.1007/s00267-007-9054-6.

Ramos, M.C., Porta, J., 1997. Analysis of design criteria for vineyard terraces in the Mediterranean area of north east Spain. Soil Technol. 10 (2), 155-166, http://dx. doi.org/10.1016/S0933-3630(96)00006-2.

Roose, E., Sabir, M., 2002. Stratégies traditionnelles de conservation de leau et des sols dans le bassin méditerranéen: classification en vue dun usage renouvellé. Bull. Réseau Eros. 3, 3-44.

Saunders, W., 1999. Preparation of DEMs for Use in Environmental Modeling Analysis. San Diego, California.

Stanchi, S., Freppaz, M., Agnelli, A., Reinsch, T., Zanini, E., 2012. Properties, best management practices and conservation of terraced soils in southern Europe (from Mediterranean areas to the Alps): a review. Quat. Int. 265, 90-100, http://dx.doi. org/10.1016/j.quaint.2011.09.015.

Stehle, S., Elsaesser, D., Gregoire, C., Imfeld, G., Niehaus, E., Passeport, E., Payraudeau, S., Schäfer, R.B., Tournebize, J., Schulz, R., 2011. Pesticide risk mitigation by vegetated treatment systems: a meta-analysis. J. Environ. Qual. 40 (4), 1068-1080, http://dx.doi.org/10.2134/jeq2010.0510.

Tarolli, P., Preti, F., Romano, N., 2014. Terraced landscapes: from an old best practice to a potential hazard for soil degradation due to land abandonment. Anthropocene 6, 10-25, http://dx.doi.org/10.1016/j.ancene.2014.03.002.

Tarolli, P., Sofia, G., Calligaro, S., Prosdocimi, M., Preti, F., Dalla Fontana, G., 2015. Vineyards in terraced landscapes: new opportunities from LiDAR data. Land Degrad. Dev. 26 (January (1)), 92-102, http://dx.doi.org/10.1002/ldr.2311, ISSN 1099-145X.

Termorshuizen, J.W., Opdam, P., 2009. Landscape services as a bridge between landscape ecology and sustainable development. Landsc. Ecol. 24 (8), 1037-1052, http://dx.doi.org/10.1007/s10980-008-9314-8.

Wang, L., Liu, H., 2006. An efficient method for identifying and filling surface depressions in digital elevation models for hydrologic analysis and modelling. Int. J. Geogr. Inf. Sci. 20 (2), 193-213, http://dx.doi.org/10.1080/13658810500433453.

Wheaton, R.Z., 2001. Terracing as a Best Management Practice for Controlling Erosion and Protecting Water Quality. Purdue University, Cooperative Extension Service.

Zevenbergen, L.W., Thorne, C.R., 1987. Quantitative analysis of land surface topography. Earth Surf. Process. Landf. 12 (1), 47-56. 